\title{
Differential diagnosis between chronic pancreatitis and pancreatic cancer: value of the detection of KRAS2 mutations in circulating DNA
}

\author{
F Maire*,', S Micard'2, P Hammel', H Voitot ${ }^{3}$, P Lévy', P-H Cugnenc ${ }^{4}$, P Ruszniewski' and P Laurent Puig ${ }^{2,4}$ \\ 'Fédération Médico-Chirurgicale d'Hépato-Gastroentérologie, Hôpital Beaujon, AP-HP, 92110 Clichy, France; ${ }^{2}$ U490 INSERM Laboratoire de Toxicologie \\ Moléculaire, 45 rue des Saints-Pères 75006 Paris, France; ${ }^{3}$ Laboratoire de Biochimie, Hôpital Beaujon, 92110 Clichy, France; ${ }^{4}$ Service de Chirurgie \\ Digestive et Oncologie, Hôpital Européen Georges Pompidou, 75015 Paris, France
}

\begin{abstract}
KRAS2 mutations in codon 12 have been detected in about $80 \%$ of pancreatic cancers. The aim of this study was to evaluate the value of KRAS2 mutations detection in circulating deoxyribo nucleic acid to differentiate pancreatic cancer from chronic pancreatitis. Circulating deoxyribo nucleic acid was isolated from serum in 47 patients with histologically proven pancreatic adenocarcinomas (26 males, median age 65 years) and 31 controls with chronic pancreatitis (26 males, median age 48 years). Mutations at codon 12 of KRAS2 gene were searched for using polymerase chain reaction and allele specific amplification. Serum carbohydrate antigen 19.9 levels were also determined. KRAS2 mutations were found in 22 patients (47\%) with pancreatic cancer and in four controls with chronic pancreatitis $(13 \%)(P<0.002)$. None of the latter developed a pancreatic cancer within the 36 months of median follow-up. The sensitivity, specificity, positive and negative predictive values of serum serum KRAS2 mutations for the diagnosis of pancreatic cancer were 47, 87, 85 and 52\%, respectively. KRAS2 mutations were not related to age, gender, smoking habit, tumour stage, or survival. Among the 26 patients with normal or non-contributive (due to cholestasis) serum carbohydrate antigen 19.9 levels, 14 (54\%) had KRAS2 mutations. The combination of KRAS2 and carbohydrate antigen 19.9 gave a sensitivity, specificity, positive and negative predictive values for the diagnosis of pancreatic cancer of $98,77,87$ and 96\%, respectively. Detection of KRAS2 mutations in circulating deoxyribo nucleic acid has a low sensitivity but a specificity about $90 \%$ for the diagnosis of pancreatic cancer. It seems particularly useful when serum carbohydrate antigen 19.9 levels are normal or inconclusive. A combined normal serum carbohydrate antigen 19.9 and absence of circulating KRAS2 mutations makes the diagnosis of pancreatic cancer extremely unlikely.

British Journal of Cancer (2002) 87, 55 I -554. doi:I0.I038/sj.bjc.6600475 www.bjcancer.com
\end{abstract}

(c) 2002 Cancer Research UK

Keywords: KRAS2 mutations; circulating DNA; pancreatic adenocarcinoma; chronic pancreatitis

Five-year survival in patients with pancreatic adenocarcinomas is less than $5 \%$, partly due to advanced disease at diagnosis. The differentiation between pancreatic cancer and chronic pancreatitis can be particularly difficult leading to inappropriate treatment. Serum carbohydrate antigen 19.9 (Ca 19.9) levels are elevated in $80 \%$ of pancreatic cancer patients, but can also be increased in $20 \%$ of patients with chronic pancreatitis (Satake and Takeuchi, 1994; Nouts et al, 1998). Moreover, pancreatic inflammation, as observed in chronic pancreatitis, can be mistaken on imaging as cancer and inversely. An accurate and non-invasive test to differentiate pancreatic cancer from chronic pancreatitis would be extremely helpful.

Previous studies have reported KRAS2 gene mutations (almost always confined to codon 12) in 75 to $95 \%$ of exocrine pancreatic cancer (Caldas and Kern, 1995). KRAS2 mutations provoke activation of nuclear transcriptor factors, resulting in cellular proliferation and also in tumour angiogenesis as reported recently (Banerjee et al, 2000; Ikeda et al, 2001). Detection of KRAS2 muta-

*Correspondence: F Maire; E-mail: frederique.maire@bjn.ap-hop-paris.fr Revised 16 May 2002; accepted 23 May 2002 tions were first reported in surgically removed pancreatic tumoural tissue or at autopsy (Almoguera et al, 1988; Tada et al, 1991). Thereafter mutations were discovered in 63 to $83 \%$ of samples of pure pancreatic juice or main pancreatic duct brushing obtained during endoscopic retrograde pancreatography (Iguchi et al, 1996; Kondo et al, 1997; Tada et al, 1998; Van Laethem et al, 1998; Okai et al, 1999; Watanabe et al, 1999; Ha et al, 2001; Pugliese et al, 2001; Seki et al, 2001) or at fine-needle tumour aspiration (Pabst et al, 1999; Puig et al, 2000), and in 20 to 54\% of stools (Caldas et al, 1994; Wenger et al, 1999) from patients with pancreatic cancer. Circulating deoxyribo nucleic acid (DNA) was first detected in serum or plasma of normal subjects in 1975 (Steinman, 1975). Since then, mutations in the KRAS2 gene have been detected in the plasma of patients with colorectal, lung and haematological cancers (Anker et al, 1997). To date, few studies have reported KRAS2 mutations in circulating DNA in patients with pancreatic cancer with a wide spectrum of sensitivity (27 to 81\%) (Sorenson et al, 1994; Mulcahy et al, 1998; Yamada et al, 1998; Castells et al, 1999; Porta et al, 1999; Theodor et al, 2000). The aim of our study was to evaluate the value of KRAS2 mutation detection in circulating DNA in a large series of patients to differentiate pancreatic adenocarcinoma from chronic pancreatitis. 


\section{PATIENTS AND METHODS}

\section{Selection and outcome of patients}

Between January 1995 and 1999, 47 patients (26 males and 21 females, median age 65 years (range $39-84)$ ) with pancreatic ductal adenocarcinoma were included in the study. In all of them, diagnosis was confirmed by pathological examination of pancreatic tumour obtained by fine needle aspiration during endoscopic ultrasonography $(n=42)$ or operative procedure $(n=5)$. Tumour staging was established by abdominal computed tomography, endoscopic ultrasonography or operative findings: stage I $(n=5,11 \%)$, stage II or III $(n=19,40 \%)$ and stage IV $(n=23,49 \%)$ according to the TNM classification (UICC, 1997). Five patients underwent surgical resection, 32 patients received systemic chemotherapy and/or radiotherapy and 10 symptomatic treatment. Median follow-up was 6 months (range 1-24). At the end of the study, all but four patients with pancreatic cancer were dead.

\section{Control group}

A control group was recruited during the same time in the same centre and included 31 patients with chronic pancreatitis (26 men and five women, median age 48 years (range 20-64)). Diagnosis of chronic pancreatitis relied upon the presence of pancreatic calcifications and/or irregularity of pancreatic ducts, according to Cambridge Classification (Axon et al, 1984) on computed tomography scan and endoscopic retrograde pancreatography, respectively. Etiology of chronic pancreatitis was alcoholic in 30 patients and idiopathic in one patient. No case of pancreatic cancer occurred during the 36-month follow-up in these 31 patients.

\section{DNA extraction and quantification}

Peripheral venous blood samples were collected after informed consent in patients and controls. Blood samples were centrifuged, serum was removed and stored at $-20^{\circ} \mathrm{C}$ until use. DNA was extracted from serum by using the QIAmp Blood Kit (Qiagen, Courtaboeuf, France) according to the blood and body fluid protocol recommended by the manufacturer. Two millilitres of serum were used, and a DNA elution volume of $50 \mu \mathrm{l}$ was obtained by extraction. The DNA elution was then concentrated to a final volume of $15 \mu \mathrm{l}$.

Quantification of serum DNA was performed for all samples using a volume of $3 \mu \mathrm{l}$ of DNA elution obtained after Qiagen extraction by fluorescence emission after intercalation of Hœschst dye. The fluorescence was read by DyNA Quantô 200 fluorimeter, using the cuve and capillary DyDNA Capillary Cuvette Adaptor Kit (Pharmacia Biotech, Orsay, France). The threshold of DNA detec-

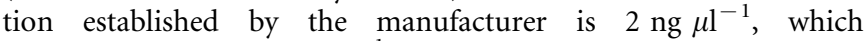
corresponds to $100 \mathrm{ng} \mathrm{ml}^{-1}$ serum in our extraction protocol (Coulet et al, 2000).

\section{Detection of KRAS2 gene mutations}

Only G12D mutations in codon 12 of the KRAS2 gene were searched for using allele-specific amplification, with the following primers: 5'-CTTGTGGTAGTTGGAGCTAA-3', 5'-AATGGTCCTGCACCAGTAATATG-3'. Amplifications were performed with $0.3 \mu \mathrm{M}$ of each primers, $200 \mu \mathrm{M}$ of each deoxynucleotide triphosphate (dNTP), $1.5 \mathrm{mM}$ of $\mathrm{MgCl}_{2}, 0.025$ units per $\mu \mathrm{l}$ of AmpliTaq Gold polymerase Cetus (Perkin Elmer), $2.5 \mu \mathrm{l}$ or $5 \mu \mathrm{l}$ of $10 \times$ buffer, $5 \mu \mathrm{l}$ of the concentrated DNA elution was used as template in a $50 \mu \mathrm{l}$ volume reaction. Polymerase chain reaction (PCR) with serum DNA was performed $10 \mathrm{~min}$ at $94^{\circ} \mathrm{C}$, followed by 60 cycles of $94^{\circ} \mathrm{C}$ for $30 \mathrm{~s}, 61^{\circ} \mathrm{C}$ for $30 \mathrm{~s}, 72^{\circ} \mathrm{C}$ for $1 \mathrm{~min}$ and a final extension of $10 \mathrm{~min}$ at $72^{\circ} \mathrm{C}$. Controls without DNA and positive controls were performed for each set of PCR reactions. PCR products were separated by electrophoresis in a $6 \%$ acrylamide gel and stained with ethidium bromide.

\section{Serum Ca 19.9 dosage}

The serum value of Ca 19.9 was measured with a commercial solidphase double-antibody sandwich immunoassay (Roche Laboratories, Basel, Switzerland). The upper limit of normal value was $37 \mathrm{UI} \mathrm{ml}{ }^{-1}$. All patients and controls also underwent biochemical liver tests. Cholestasis was defined by alkaline phosphatase levels above twice the normal value.

\section{Statistical analysis}

For each marker (serum KRAS2 mutations and Ca 19.9), sensitivity, specificity, positive and negative predictive values were calculated. Thereafter, the combination of both markers (i.e., one and/or the other positive) was studied. The chi-squared test was used to compare the occurrence of KRAS2 mutations. Differences were considered significant when $P<0.05$.

\section{RESULTS}

\section{Circulating DNA quantification}

Adequate DNA was extracted from the serum in sufficient quantities for analysis in all patients and controls. All patients but one had a serum DNA concentration higher than the threshold of detection of $100 \mathrm{ng} \mathrm{ml}^{-1}$. The mean concentrations of DNA extracted from serum of patients with pancreatic cancer and chronic pancreatitis were $730 \pm 90 \mathrm{ng} \mathrm{ml}^{-1}$ and $560 \pm 93 \mathrm{ng} \mathrm{ml}^{-1}$, respectively $(P=0.19)$.

\section{KRAS2 mutations in circulating DNA}

KRAS2 mutations were identified in the serum of 22 patients $(47 \%)$ with pancreatic adenocarcinoma and in four patients $(13 \%)$ with chronic pancreatitis $(P<0.002)$. The sensitivity, specificity, positive and negative predictive values of serum KRAS2 mutations for the diagnosis of pancreatic cancer were 47, 87, 85 and $52 \%$, respectively. There were no statistically significant differences in age, gender, smoking, tumour stage and survival, according to presence or absence of plasma KRAS2 mutations.

Among patients with chronic pancreatitis, no cancer occurred after a mean follow-up of 36 months (range 13-64), even in those with positive KRAS2 mutations (with follow-up of 40 months, range 20-61), assessed by clinical observation and abdominal computed tomography scan.

\section{Serum Ca 19.9 levels}

The sensitivity, specificity, positive and negative predictive values of abnormal $\mathrm{Ca} 19.9$ levels for the diagnosis of pancreatic cancer were 91, 87, 91 and 87\%, respectively (Table 1). Serum Ca 19.9 levels were normal or non interpretable due to cholestasis in 26 patients. Among them, 14 (54\%) patients had serum KRAS2 mutations. Combination of both tests increased sensitivity to $98 \%$ with a negative predictive value of $96 \%$ for the diagnosis of pancreatic cancer (Table 1)

\section{DISCUSSION}

In the present study, only the most frequent KRAS2 gene mutation G12D (aspartic acid) observed in pancreatic cancer (Iguchi et al, 1996; Tada et al, 1998; Castells et al, 1999; Watanabe et al, 1999) was analysed in the serum of patients and controls, in 
Table I Accuracy of serum KRAS2 mutation detection, serum Ca|9.9 levels, and both for the diagnosis of pancreatic cancer

\begin{tabular}{lccc}
\hline & $\begin{array}{c}\text { Serum KRAS2 } \\
\text { mutations }\end{array}$ & $\begin{array}{c}\text { Serum } \\
\text { Cal9.9 }\end{array}$ & $\begin{array}{c}\text { Both tests } \\
\text { combined }\end{array}$ \\
\hline Sensitivity (\%) & 47 & 91 & 98 \\
Specificity (\%) & 87 & 87 & 77 \\
Positive predictive value (\%) & 85 & 91 & 87 \\
Negative predictive value (\%) & 52 & 87 & 96 \\
\hline
\end{tabular}

order to limit the cost of such test and to validate it in clinical practice.

Our study underlines the high feasibility of KRAS2 mutations analysis, as circulating DNA was obtained in sufficient quantities in all patients. Mean serum DNA concentration were $730 \mathrm{ng} \mathrm{ml}^{-1}$, which is comparable to that observed in the series of Mulcahy et al (1998).

In the present study, detection of KRAS2 mutations in circulating DNA had a low sensitivity but a high specificity for the diagnosis of pancreatic cancer. The sensitivity $(47 \%)$ was in agreement with previous studies (27 to 81\%) (Mulcahy et al, 1998; Yamada et al, 1998; Castells et al, 1999; Porta et al, 1999; Theodor et al, 2000; Zambon et al, 2000), although the search for five other possible KRAS2 mutations in codon 12 was not performed. Higher KRAS2 mutation prevalences have been reported in pancreatic or duodenal juice (63 to $87 \%$ ), due probably to higher DNA tumour content in pancreatic juice as compared to plasma (Wilentz et al, 1998; Van Laethem et al, 1998; Watanabe et al, 1999). Use of samples of pancreatic juice however requires invasive procedures (fine-needle aspiration during endoscopic ultrasonography or endoscopic retrograde pancreatography). Three studies have reported a higher specificity of serum KRAS2 mutations compared to the current study (100 vs 87\%), but their control groups included few patients and essentially healthy subjects (Mulcahy et al, 1998; Porta et al, 1999; Theodor et al, 2000). Since KRAS2 mutations have been reported in pancreatic tissue or juice from $6-42 \%$ of patients with chronic pancreatitis (Furuya et al, 1997; Mulligan et al, 1999; Lüttges et al, 2000; Ha et al, 2001), and knowing that a part of this mutated DNA can be released into circulation (Yamada et al, 1998), the control group should include patients with chronic pancreatitis. In the series published by Castells et al (1999) with the largest control group (including patients with chronic pancreatitis), specificity was comparable (94\%) to the present study, and increased in the presence of a pancreatic mass. The accuracy of serum KRAS2 mutation detection in the differential diagnosis between pancreatic cancer and chronic pancreatitis may be improved by performing quantitative PCR measurement of mutated DNA, in order to discriminate patients with unspecific low levels of mutated DNA (as supposed in chronic pancreatitis) from patients with high levels (pancreatic cancer), as suggested in pancreatic juice analysis by Tada et al (1998)

Serum Ca 19.9 is widely used for pancreatic cancer diagnosis with a sensitivity of $80 \%$ (Satake and Takeuchi, 1994). This marker

\section{REFERENCES}

Almoguera C, Shibata D, Forrester K, Martin J, Arnheim N, Perucho M (1988) Most human carcinomas of the exocrine pancreas contain mutant c-K-ras genes. Cell 53: 549-554

Anker P, Lefort F, Vasioukhin V, Lyautey J, Lederrey C, Chen XQ, Stroun M, Mulcahy HE, Farthing MJ (1997) K-ras mutations are found in DNA extracted from the plasma of patients with colorectal cancer. Gastroenterology 112: $1114-1120$ is not informative in $5 \%$ of population who cannot express serum Ca 19.9 due to Lewis a negative status (Narimatsu et al, 1996). However, serum Ca 19.9 lacks specificity (70 to $80 \%$ ): it can be increased in cholestasis, diabetes mellitus or chronic pancreatitis (Nouts et al, 1998). In the present study, serum Ca 19.9 had very good specificity (87\%), similar to that of serum KRAS2 mutations. Combination of both tests could be useful to assess cancer diagnosis in patients with normal or non contributive $\mathrm{Ca} 19.9$ due to cholestasis or negative Lewis a antigen status, and to exclude cancer diagnosis when both tests are negative (predictive negative value of $96 \%)$.

In the present study, the presence of KRAS2 mutations in serum was not correlated to age, gender and smoking habit. It was neither correlated to tumour stage since mutations were detected in plasma of patients with non metastatic tumours, which supports the hypothesis that KRAS2 mutations are early events in pancreatic carcinogenesis (Jimenez et al, 1999). Two studies in the literature are in agreement with this result (Yamada et al, 1998; Theodor et al, 2000), but another one found a statistically significant relation between circulating DNA KRAS2 mutations and poor prognosis (Castells et al, 1999). Yamada et al (1998) have reported disappearance of detectable mutation in plasma after tumoural resection or radio-chemotherapy in six of nine patients, suggesting KRAS2 mutations may be used as a tumour relapse marker.

Screening for malignancy in patients with chronic pancreatitis is a difficult challenge. Patients with chronic pancreatitis have an increased risk of pancreatic cancer, estimated at $1.8 \%$ at 10 years and $4 \%$ at 20 years (Lowenfels et al, 1993). Three studies have evaluated occurrence of pancreatic cancer in patients with chronic pancreatitis with respect to KRAS2 mutations in pancreatic juice: only one found an increase in pancreatic cancer in patients with KRAS2 mutations with methodological limitations (few cases, early diagnosis of cancer after inclusion) (Furuya et al, 1997; Lohr et al, 2001; Queneau et al, 2001). To our knowledge, no study focused on the incidence of pancreatic cancer in patients with chronic pancreatitis according to serum KRAS2 mutations. In the present study, follow-up was too short to demonstrate an increased risk of cancer in patients with chronic pancreatitis and serum KRAS2 mutations.

In conclusion, although detection of plasma KRAS2 mutations in circulating DNA is not a definitive argument for malignancy, it could contribute to cancer diagnosis. This test seems particularly interesting in patients with normal or inconclusive Ca 19.9 levels due to cholestasis or Lewis a negative status. In patients with normal serum Ca 19.9 levels and no KRAS2 mutation, the diagnosis of pancreatic cancer can be excluded with almost certainty.

\section{ACKNOWLEDGEMENTS}

Région Ile de France, Ligue Nationale Contre le Cancer.
Axon AT, Classen M, Cotton PB, Cremer M, Freeny PC, Lees WR (1984) Pancreatography in chronic pancreatitis: international definitions. Gut 25: $1107-1112$

Banerjee SK, Zoubine MN, Mullick M, Weston AP, Cherian R, Campbell DR (2000) Tumor angiogenesis in chronic pancreatitis and pancreatic adenocarcinoma: impact of K-ras mutations. Pancreas 20: $248-255$ 
Caldas C, Hahn SA, Hruban RH, Redston MS, Yeo CJ, Kern SE (1994) Detection of K-ras mutations in the stool of patients with pancreatic adenocarcinoma and pancreatic ductal hyperplasia. Cancer Res 54: $3568-3573$

Caldas C, Kern SE (1995) K-ras mutation and pancreatic adenocarcinoma. Int J Pancreatol 18: 1-6

Castells A, Puig P, Mora J, Boadas J, Boix L, Urgell E, Sole M, Capella G, Lluis F, Fernandez-Cruz L, Navarro S, Farre A (1999) K-ras mutations in DNA extracted from the plasma of patients with pancreatic carcinoma: diagnostic utility and prognostic significance. J Clin Oncol 17: 578-584

Coulet F, Blons H, Cabelguenne A, Lecomte T, Lacourreye O, Brasnu D, Beaune P, Zucman J, Laurent-Puig P (2000) Detection of plasma tumor DNA in head and neck squamous cell carcinoma by microsatellite typing and p53 mutation analysis. Cancer Res 60: 707-711

Furuya N, Kawa S, Akamatsu T, Furihata K (1997) Long-term follow-up of patients with chronic pancreatitis and K-ras gene mutation detected in pancreatic juice. Gastroenterology 113: $593-598$

Ha A, Watanabe H, Yamaguchi Y, Ohtsubo K, Wang Y, Motoo Y, Okai T, Wakabayahi T, Sawabu N (2001) Usefulness of supernatant of pancreatic juice for genetic analysis of K-ras in diagnosis of pancreatic carcinoma. Pancreas 23: $356-363$

Iguchi H, Sugano K, Fukayama N, Ohkura H, Sadamoto K, Ohkoshi K, Seo Y, Tomoda H, Funakoshi A, Wakasugi H (1996) Analysis of Ki-ras codon 12 mutations in the duodenal juice of patients with pancreatic cancer. Gastroenterology 110: $221-226$

Ikeda N, Nakajima Y, Sho M, Adachi M, Huang CL, Iki K, Kanehiro H, Hisanaga M, Nakano H, Miyake M (2001) The association of K-ras gene mutation and vascular endothelial growth factor gene expression in pancreatic carcinoma. Cancer 92: 488-499

Jimenez RE, Warshaw AL, Z'graggen K, Hartwig W, Taylor DZ, Compton CC, Fernandez-del Castillo C (1999) Sequential accumulation of K-ras mutations and p53 overexpression in the progression of pancreatic mucinous cystic neoplasms to malignancy. Ann Surg 230: 501-509

Kondo H, Sugano K, Fukayama N, Hosokawa K, Ohkura H, Ohtsu A, Mukai K, Yoshida S (1997) Detection of K-ras gene mutations at codon 12 in the pancreatic juice of patients with intraductal papillary mucinous tumors of the pancreas. Cancer 79: $900-905$

Lohr M, Muller P, Mora J, Brinkmann B, Ostwald C, Farre A, Lluis F, Adam U, Stubbe J, Plath F, Nizze H, Hopt UT, Barten M, Capella G, Liebe S (2001) p53 and K-ras mutations in pancreatic juice samples from patients with chronic pancreatitis. Gastrointest Endosc 53: 734-743

Lowenfels AB, Maisonneuve P, Cavallini G, Ammann RW, Lankisch PG, Andersen JR, Dimagno EP, Andren-Sandberg A, Domellof L (1993) Pancreatitis and the risk of pancreatic cancer. International Pancreatitis Study Group. N Engl J Med 328: $1433-1437$

Lüttges J, Diederichs A, Menke MA, Vogel I, Kremer B, Kloppel G (2000) Ductal lesions in patients with chronic pancreatitis show K-ras mutations in a frequency similar to that in the normal pancreas and lack nuclear immunoreactivity for p53. Cancer 88: 2495-2504

Mulcahy HE, Lyautey J, Lederrey C, qi Chen X, Anker P, Alstead EM, Ballinger A, Farthing MJ, Stroun M (1998) A prospective study of K-ras mutations in the plasma of pancreatic cancer patients. Clin Cancer Res 4: $271-275$

Mulligan NJ, Yang S, Andry C, Klein M, O’Brien MJ (1999) The role of p21ras in pancreatic neoplasia and chronic pancreatitis. Hum Pathol 30: $602-610$

Narimatsu H, Iwasaki H, Nishihara S, Kimura H, Kudo T, Yamauchi Y, Hirohashi S (1996) Genetic evidence for the Lewis enzyme, which synthesizes type-1 Lewis antigens in colon tissue, and intracellular localization of the enzyme. Cancer Res 56: 330-338

Nouts A, Lévy P, Voitot H, Bernades P (1998) Valeur diagnostique de l'antigène sérique $\mathrm{Ca}$ 19-9 au cours de la pancréatite chronique et de l'adénocarcinome pancréatique. Gastroenterol Clin Biol 22: 152 - 159

Okai T, Watanabe H, Yamaguchi Y, Mouri I, Motoo Y, Sawabu N (1999) EUS and K-ras analysis of pure pancreatic juice collected via a duodenoscope after secretin stimulation for diagnosis of pancreatic mass lesion: a prospective study. Gastrointest Endosc 50: 797-803
Pabst B, Arps S, Binmoeller K, Thul R, Walsemann G, Fenner C, Klapdor R (1999) Analysis of K-ras mutations in pancreatic tissue after fine needle aspirates. Anticancer Res 19: $2481-2483$

Porta M, Malats N, Jariod M, Grimalt JO, Rifa J, Carrato A, Guarner L, Salas A, Santiago-Silva M, Corominas JM, Andreu M, Real FX (1999) Serum concentrations of organochlorine compounds and K-ras mutations in exocrine pancreatic cancer. PANKRAS II Study Group. Lancet 354: $2125-2129$

Pugliese V, Pujic N, Saccomanno S, Gatteschi B, Pera C, Aste H, Ferrara GB, Nicolo G (2001) Pancreatic intraductal sampling during ERCP in patients with chronic pancreatitis and pancreatic cancer: cytologic studies and kras-2 codon 12 molecular analysis in 47 cases. Gastrointest Endosc 54: 595-599

Puig P, Urgell E, Capella G, Sancho FJ, Pujol J, Boadas J, Farre A, Lluis F, Gonzalez-Sastre F, Mora J (2000) A highly sensitive method for K-ras mutation detection is useful in diagnosis of gastrointestinal cancer. Int $J$ Cancer 85: 73-77

Queneau PE, Adessi GL, Thibault P, Cleau D, Heyd B, Mantion G, Carayon P (2001) Early detection of pancreatic cancer in patients with chronic pancreatitis: diagnostic utility of a K-ras point mutation in the pancreatic juice. Am J Gastroenterol 96: 700-704

Satake K, Takeuchi T (1994) Comparison of CA19-9 with other tumor markers in the diagnosis of cancer of the pancreas. Pancreas 9: 720-724

Seki K, Suda T, Aoyagi Y, Sugawara S, Natsui M, Motoyama H, Shirai Y, Sekine T, Kawai H, Mita Y, Waguri N, Kuroiwa T, Igarashi M, Asakura H (2001) Diagnosis of pancreatic adenocarcinoma by detection of human telomerase reverse transcriptase messenger RNA in pancreatic juice with sample qualification. Clin Cancer Res 7: 1976-1981

Sorenson GD, Pribish DM, Valone FH, Memoli VA, Bzik DJ, Yao SL (1994) Soluble normal and mutated DNA sequences from single-copy genes in human blood. Cancer Epidemiol Biomarkers Prev 3: 67-71

Steinman CR (1975) Free DNA in serum and plasma from normal adults. $J$ Clin Invest 56: $512-515$

Tada M, Omata M, Ohto M (1991) Clinical application of ras gene mutation for diagnosis of pancreatic adenocarcinoma. Gastroenterology 100: 233 238

Tada M, Teratani T, Komatsu Y, Kawabe T, Shiratori Y, Omata M (1998) Quantitative analysis of ras gene mutation in pancreatic juice for diagnosis of pancreatic adenocarcinoma. Dig Dis Sci 43: 15-20

Theodor L, Melzer E, Sologov M, Bar-Meir S (2000) Diagnostic value of K-ras mutations in serum of pancreatic cancer patients. Ann NY Acad Sci 906: $19-24$

UICC (1997) TNM classification of malignant tumours, 5th edn, Sobin LH, Wittekind Ch (eds). Berlin Heildeberg, New York: Springer-Verlag

Van Laethem JL, Bourgeois V, Parma J, Delhaye M, Cochaux P, Velu T, Deviere J, Cremer M (1998) Relative contribution of Ki-ras gene analysis and brush cytology during ERCP for the diagnosis of biliary and pancreatic diseases. Gastrointest Endosc 47: 479-485

Watanabe H, Ha A, Hu YX, Ohtsubo K, Yamaguchi Y, Motoo Y, Okai T, Toya D, Tanaka N, Sawabu N (1999) K-ras mutations in duodenal aspirate without secretin stimulation for screening of pancreatic and biliary tract carcinoma. Cancer 86: $1441-1448$

Wenger FA, Zieren J, Peter FJ, Jacobi CA, Muller JM (1999) K-ras mutations in tissue and stool samples from patients with pancreatic cancer and chronic pancreatitis. Langenbecks Arch Surg 384: 181-186

Wilentz RE, Chung CH, Sturm PD, Musler A, Sohn TA, Offerhaus GJ, Yeo CJ, Hruban RH, Slebos RJ (1998) K-ras mutations in the duodenal fluid of patients with pancreatic carcinoma. Cancer 82: 96-103

Yamada T, Nakamori S, Ohzato H, Oshima S, Aoki T, Higaki N, Sugimoto K, Akagi K, Fujiwara Y, Nishisho I, Sakon M, Gotoh M, Monden M (1998) Detection of K-ras gene mutations in plasma DNA of patients with pancreatic adenocarcinoma: correlation with clinicopathological features. Clin Cancer Res 4: 1527 - 1532

Zambon C, Navaglia F, Basso D, Gallo N, Greco E, Piva MG, Fogar P, Pasquali C, Pedrazzoli S, Plebani M (2000) ME-PCR for the identification of mutated K-ras in serum and bile of pancreatic cancer patients: an unsatisfactory technique for clinical applications. Clin Chim Acta 302: 35-48 